\title{
The interaction of fine particles with stranded oil*
}

\author{
Edward H. Owens \\ Owens Coastal Consultants Ltd, 755 Winslow Way East, Bainbridge Island, WA 98110, USA
}

\begin{abstract}
The interaction of micron-sized mineral particles with stranded oil reduces its adhesion to solid surfaces, such as sediments or bedrock. The net result is the formation of stable, micron-sized, oil droplets that disperse into the water column. In turn, the increase in surface area makes the oil more available for biodegradation. Oil and Fine-particle Interaction ('OFI') can explain how oiled shorelines are cleaned naturally in the absence of wave action in very sheltered coastal environments. Fine-particle interaction can be accelerated during a spill response by relocating the oiled sediments into the surf zone. This has been achieved successfully on two occasions to date: the Tampa Bay response in Florida, and the Sea Empress operation in Wales. Sediment relocation also causes physical abrasion by the hydraulic action of waves so that the processes of fine-particle interaction and surf washing usually occur in combination on open coasts.
\end{abstract}

\section{INTRODUCTION}

A radical change in the understanding of a topic usually is not attributable to a single event or study. The natural cleaning and removal processes of stranded oil from shorelines on exposed coasts have been understood for many years; they involve a simple relationship between the level of wave energy and the location of the oil. On open coasts, oil in the zone of normal wave action is rapidly abraded by physical processes and removed into the water column. The understanding of how shorelines clean themselves in the absence of wave energy and erosion, however, was not understood until a study conducted following the Exxon Valdez oil spill in 1989 provided an explanation [1]. During laboratory work on oiled sediments collected from Prince William Sound, Alaska, Bragg and his co-workers observed a process that involved the creation, in seawater, of a stable emulsion of micron-sized droplets of oil surrounded by micron-sized clays. The process of clay-oil flocculation reduced the adhesion of oil to other materials, such as sediment or bedrock and, once formed, the clay-oil flocs were easily removed by even gentle water motion.

From a scientific point of view this discovery was not new. Studies on the surface properties of mineral, organic, and biologic fines had provided a body of knowledge related to the interactions of fine particles with hydrocarbons, and a number of investigators had studied these interactions as a mechanism for the adsorption and transport of hydrocarbons in seawater (e.g. [2,3]). These studies focused primarily on the offshore environment. The new element provided by the Bragg study was the recognition that this active, natural process was a mechanism that could explain how and why residual oil is removed from shorelines in the absence of hydraulic activity (waves and currents).

The implications of the laboratory studies by Bragg's team were quickly seen to be significant in developing an explanation for the documented large-scale removal of oil from sheltered shorelines in Prince William Sound that had occurred during the 1989-90 winter months [4]. The natural cleaning of exposed shorelines in Prince William Sound could be explained easily as a consequence of hydraulic removal by winter wave action. The fact that many sections of oiled shoreline were naturally cleaned in the absence of wave action, in sheltered areas such as Northwest Bay or Herring Bay, could now be explained by the mechanism of clay-oil flocculation. Over the two years that followed, the new understanding gained from this study was applied to explain the changes that had been observed or documented on numerous other spill situations $[5,6]$.

*Pure Appl. Chem. 71(1) (1999). An issue of special reports reviewing oil spill countermeasures. 
The key paradigm shift that occurred as a result of Bragg's work was enabled by the understanding that investigators now had at their disposal an explanation for natural self-cleaning in the presence and in the absence of both wave energy and coastal erosion. This understanding does not mean that clay-oil flocculation is the only process that is active in degrading and removing stranded oil in low-energy environments, as photo-oxidation, biodegradation, and a range of other fine-particle related processes also are active. The importance of this study is that it identified a particular type of physical process that would now have to be factored into all future investigations on the fate and persistence of stranded oil.

\section{FIRST STEPS}

The cleanup program in Alaska following the spill from the Exxon Valdez in March 1989 focused on the removal of bulk oil residues from the shoreline. The 1989 cleanup operations treated approximately $780 \mathrm{~km}$ of oiled coast in Prince William Sound. As part of the monitoring program initiated by Exxon in May 1989, a set of 20 stations were occupied in Prince William Sound to document long-term changes in oil conditions on different shoreline environments [7]. The treatment removed considerable amounts of oil, but residues remained on many sections of shoreline by the end of the summer. During the winter of 1989-90, as expected, surface oil residues were reduced by winter storm-wave action on the open and exposed coasts in the Sound. Unexpectedly, oil residues also were reduced in low-energy bays sheltered from the winter wave action. Data from four low wave-energy stations are presented in Table 1. All of these show a large change in the surface oil cover values, even though these were described as 'sheltered wave-energy environments'. One of the most valuable data series is that from Site AP-4, on Ingot Island, where wave data were observed for the period mid-November 1989 through mid-April 1990, using a time-lapse camera. Wave heights equal to or greater than $0.5 \mathrm{~m}$ were observed on only three occasions, with the highest being $0.75 \mathrm{~m}$, and 130 of the 154 observations indicate either calm conditions or breaking waves less than $0.25 \mathrm{~m}$. Yet at this location there was a $78 \%$ reduction in the surface oiled area, from $535 \mathrm{~m}^{2}$ to $116 \mathrm{~m}^{2}$, over a 6-month period. No explanation was evident for this natural cleaning without wave action and abrasion, and such rapid weathering had not been reported from prior spills.

One of the objectives of the monitoring program was to provide estimates on the persistence of stranded oil so that plans for further treatment in 1990 could be developed as early as possible before field operations recommenced in the spring. A set of laboratory studies was designed to augment these estimates by placing oiled sediment from Prince William Sound in water columns and wave tanks to measure removal rates. The behavior of the oiled sediments in the tanks was unexpected (Table 1).

Shortly after immersion in sea water, the investigators observed and documented the dispersion of particles from the sediments [1]. Upon microscopic examination these particles proved to be clay aggregates that contained micron-sized oil droplets and bacteria (Fig. 1, 2). It was postulated that these aggregates were stabilized by the interaction between polar compounds in the oil, which were attracted to the oil surface by cations in the sea water, the sea-water cations, and charges on the mineral particle surfaces. Key conclusions from this investigation were that: (i) the formation of the oil-seawater-clay emulsion reduced the ability of the oil to adhere to the shoreline materials, facilitating removal by wave and tidal action, (ii) the structure of the emulsion increased the oil-water interfacial area by several orders of magnitude, thus making the oil more accessible to bacterial and other degradation processes, and (iii) the buoyancy and large hydrodynamic cross section of the particles of flocculated emulsion would favor dispersion and transportation and minimize the accumulation of undegraded hydrocarbon in subtidal sediments.

The implications of these laboratory studies immediately were seen to be significant in developing an explanation for the observed large-scale removal of oil from sheltered shorelines in Prince William Sound that had occurred during the 1989-90 winter months [4]. The natural cleaning of the exposed shorelines could be explained easily as a consequence of hydraulic removal by winter storm-wave action. The fact that many sections of oiled shoreline were naturally cleaned in the absence of wave action, in sheltered areas such as Northwest Bay or Herring Bay, could now be explained by the mechanism of clay-oil flocculation.

\section{NEW HORIZONS}

The knowledge gained by the Exxon Valdez technical team was used in 1993 to obtain support for the 
Table 1 Changes in shoreline oiling conditions at four sheltered locations in Prince William Sound, Alaska, winter 1989-90 (from [7])

\begin{tabular}{|c|c|c|c|c|c|c|c|c|c|}
\hline \multirow{2}{*}{$\begin{array}{l}\text { Study } \\
\text { location }\end{array}$} & \multirow[t]{2}{*}{ Fetch character } & \multirow[t]{2}{*}{ Shore type } & \multirow{2}{*}{$\begin{array}{l}\text { Beach length }(\mathrm{m}) \text {; } \\
\text { (Number of beach } \\
\text { transects) }\end{array}$} & \multicolumn{6}{|c|}{ Surface oiled area* $\left(\mathrm{m}^{2}\right)$} \\
\hline & & & & $\begin{array}{l}\text { Sept } \\
1989\end{array}$ & $\begin{array}{l}\text { Oct } \\
1989\end{array}$ & $\begin{array}{l}\text { Dec } \\
1989\end{array}$ & $\begin{array}{l}\text { Jan } \\
1990\end{array}$ & $\begin{array}{l}\text { Mar } \\
1990\end{array}$ & $\begin{array}{l}\% \\
\text { Reduction }\end{array}$ \\
\hline $\begin{array}{l}\text { AP-4 } \\
\text { Ingot Island, } \\
\text { Foul Passage }\end{array}$ & $\begin{array}{l}\text { Protected, narrow fetch } \\
\text { window to south-east and } \\
\text { north-west }\left(<15^{\circ}\right)\end{array}$ & $\begin{array}{l}\text { Poorly sorted pebbles } \\
\text { and cobbles, secondary } \\
\text { sands and granules }\end{array}$ & $\begin{array}{l}150 \mathrm{~m} \\
(8)\end{array}$ & 535 & 416 & 387 & 118 & 116 & 78 \\
\hline $\begin{array}{l}\text { AP-6 } \\
\text { Herring Bay }\end{array}$ & $\begin{array}{l}\text { Very sheltered, maximum } \\
\text { fetch } 4 \mathrm{~km}\end{array}$ & $\begin{array}{l}\text { Poorly sorted, angular } \\
\text { cobbles and pebbles }\end{array}$ & $\begin{array}{l}140 \mathrm{~m} \\
(8)\end{array}$ & 124 & 68 & - & 48 & 34 & 72 \\
\hline $\begin{array}{l}\text { AP-17 } \\
\text { Elrington Island, } \\
\text { Foxfarm Bay }\end{array}$ & $\begin{array}{l}\text { Partially sheltered; fetch } \\
<1 \mathrm{~km} \text { perpendicular to } \\
\text { beach; diffracted waves } \\
\text { from narrow window } \\
\text { with fetch } \approx 10 \mathrm{~km}\end{array}$ & $\begin{array}{l}\text { Poorly sorted pebble- } \\
\text { cobble beach }\end{array}$ & $\begin{array}{l}200 \mathrm{~m} \\
(10)\end{array}$ & 243 & 103 & 34 & 27 & - & 89 \\
\hline $\begin{array}{l}\text { AP-18 } \\
\text { Elrington Island, } \\
\text { Foxfarm Bay }\end{array}$ & $\begin{array}{l}\text { Very sheltered; fetch } \\
<1 \mathrm{~km} \text { perpendicular to } \\
\text { beach; diffracted waves } \\
\text { from narrow window } \\
\text { with fetch } \approx 10 \mathrm{~km}\end{array}$ & $\begin{array}{l}\text { Poorly sorted pebble, } \\
\text { cobble and sand beach; } \\
\text { scattered boulders }\end{array}$ & $\begin{array}{l}200 \mathrm{~m} \\
(10)\end{array}$ & 393 & 98 & 129 & 53 & 51 & 87 \\
\hline
\end{tabular}

*The 'surface oiled area' is the total observed oiled area multiplied by the percentage surface oil cover [7]. 


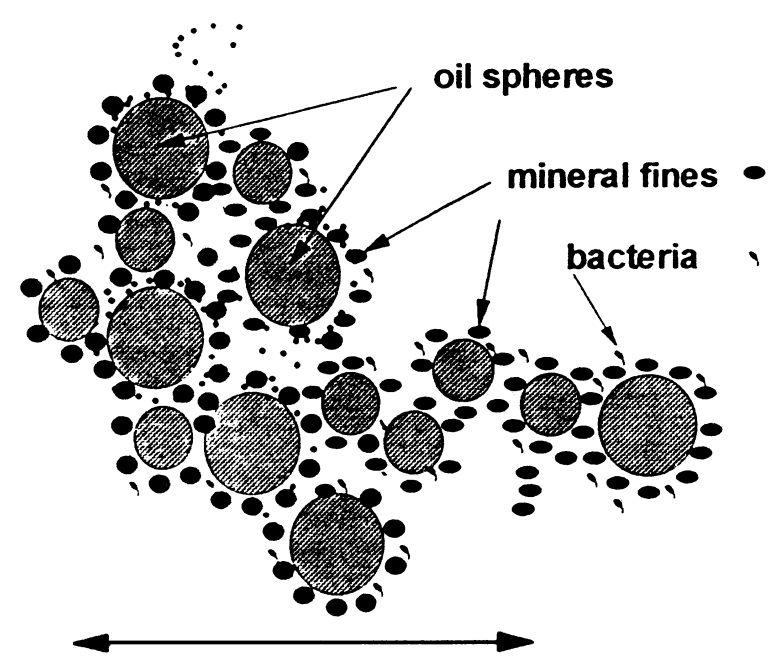

\section{0 microns}

Fig. 1 Sketch of an aggregate with clays, oil particles, and bacteria (from [8]).

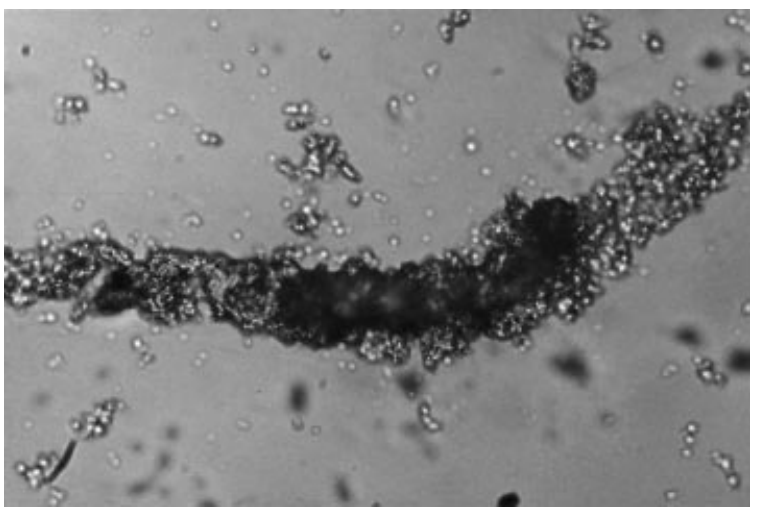

Fig. 2 Photograph of a single oil-fine particle aggregate. The clay particles in this microphotograph are 1- $\mu \mathrm{m}$ diameter illites.

collection of oil residue and beach sediment samples from a number of spill locations. Samples of sediment and oiled sediment were obtained from the shorelines of:

- Chedabucto Bay, Nova Scotia, Canada, oiled in 1970 by the tanker Arrow spill,

- the Strait of Magellan, Chile, oiled in 1974 by the tanker Metula spill,

- Baffin Island, oiled by the 1981 BIOS experiment,

- Tacoma Harbor, Washington, oiled by the 1993 Nosac Forest spill, and

- Tampa, Florida, oiled by the 1993 barge spill.

The objective of the sample collection and subsequent laboratory analyses was to determine whether the oil flocculated or was likely to have flocculated following each of these spills. The studies involved observations and experiments with oiled and un-oiled sediments from the sites, the original spilled oil (when available), and seawater that was collected at the different locations.

Of the various studies that were conducted, the most illuminating was that of the spill from the tanker Arrow, that occurred in Chedabucto Bay, Nova Scotia in February 1970. More than 72000 barrels of bunker $\mathrm{C}$ oiled an estimated $305 \mathrm{~km}$ of shoreline in the area. The cleanup operations treated about $40 \mathrm{~km}$ of the oiled coasts. A systematic ground survey of those oiled coasts in 1992 revealed that oil remained on 
only $13.5 \mathrm{~km}$ of the shoreline, indicating that approximately $250 \mathrm{~km}$ had self-cleaned over that interval. This is not surprising until a review shows that $70 \mathrm{~km}$ of very sheltered shoreline that was very heavily oiled on several occasions in 1970 had no oil residues by the time of the 1992 survey [9]. More enlightening is a 1973 survey [10] that shows that these same low-energy environments already were observed to have only 'traces or patches of oil' within a time frame of less than 3 years. These locations have short fetch areas, generally less than $5 \mathrm{~km}$ and often less than $1 \mathrm{~km}$, but the shore is rich in clays derived from abundant intertidal and backshore glacial deposits. Beach sediments collected from a very sheltered and very low-energy site were observed in the laboratory to flocculate slowly, over days, with samples of original Arrow oil. Clearly, the clay-oil flocculation process could be considered as an explanation of how much of the heavily oiled shoreline was cleaned naturally in this complex system of islands and bays in northern Chedabucto Bay.

The analyses of samples from other Arrow sites and elsewhere is discussed by Bragg \& Owens [5]. One point of note is that natural cleaning had been observed at the 1980 Baffin Island Oil Spill (BIOS) experiment site over a period of years, but that no evidence was found of accumulation of oil in the nearshore bottom sediments, based on a limited number of samples [11]. This is important as one question that arises is related to the pathway of the removed oil. The production of negatively buoyant oil aggregates would be of concern in terms of the potential effects on nearshore organisms. All of the laboratory work conducted by Bragg indicated that the aggregates were positively buoyant, which would indicate that nearshore seabed accumulations of oil would be unlikely.

\section{TAMPA BAY AND SEA EMPRESS SPILLS}

Accelerated shoreline cleanup by intentional application of the concept of oil and fine-particle interaction has been conducted on two spill response operations — the Tampa Bay spill in Florida (1993) and the Sea Empress in Wales (1996).

A spill of a no. 6 fuel oil occurred at the entrance to Tampa Bay, Florida, in August 1993 and the adjacent open-ocean sand beaches were heavily oiled a few days later. This coast is a high-value recreation shore and the objective of the cleanup was to restore the beaches to a prespill condition before the annual Labor Day vacation. After removal of the oiled sediments, either manually or mechanically, the sand retained a brown oil stain. Bulldozers and front-end loaders were used to push the surface layers of sediment into the surf zone with the anticipation that there would follow a natural cleaning of the sediment (Fig. 3). This was successful and the transport of the cleaned sediment back up the beach

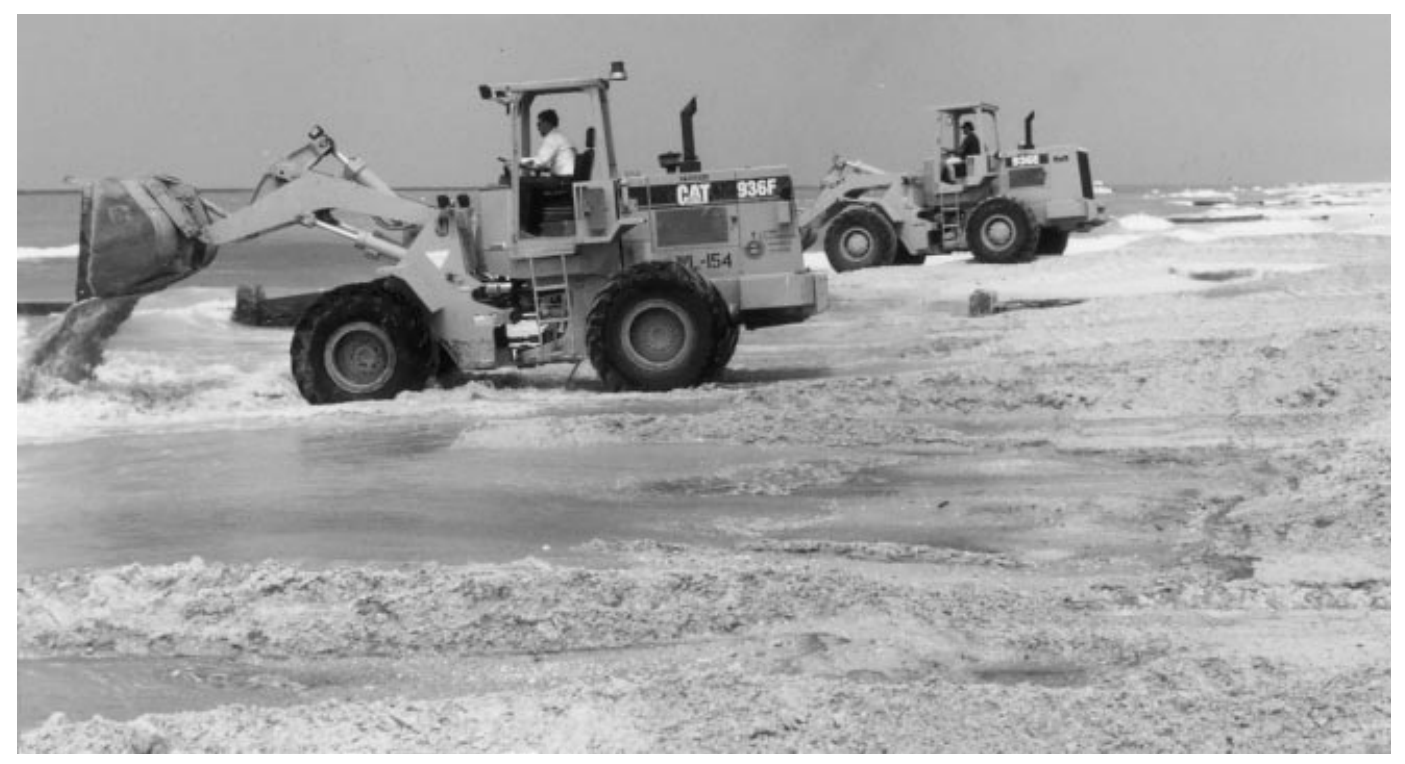

Fig. 3 Photograph of sediment relocation into the surf zone on 21 August 1993: Treasure Island, Florida. 
occurred in conditions with wave heights generally less than $30 \mathrm{~cm}$ over a period of only one or two tidal cycles [12]. The sediments were a well-sorted fine to coarse sand with a high shell fragment content and virtually no clays.

This accelerated removal showed that the process could be used as a polishing tool for shoreline cleanup. A second important point was that clay-oil flocculation was not the primary process as the mineral fines were predominantly calcareous (calcite, aragonite, halite, quartz and iron-dolomite). It would now be necessary to change the description of the process from 'clay-oil flocculation' to a term that included other types of mineral fines. In the laboratory, the response of samples of the oiled sediment when submerged in seawater was immediate: within seconds the flocculated oil separated from the brown-colored, oiled sands to produce a white, oil-free sand. The laboratory studies were able to replicate the process with other oils. No original cargo oil was available for this study but un-oiled sediments from the same beach were mixed in seawater with weathered Exxon Valdez and were documented to flocculate readily [5].

The Sea Empress spilled a cargo of Forties Blend and heavy fuel oil near Milford Haven, Wales, in February 1996. As a result of finding that clay-oil flocculation was taking place at this spill location, the planned operational response was modified so that beach sediments at Amroth were relocated to the lower intertidal zone to accelerate oil removal by surf washing (abrasion) and to expose subsurface oiled pebbles and cobbles. This action also exposed fine sediments so that the concentration of fines in the nearshore waters was increased, which promoted interaction between oil and sediment fines [13,14]. After four days of this treatment, the concentrations of oil on the beach were reduced by more than an order of magnitude. Visual observations indicate that $50 \%$ of the removal could be attributed to abrasion and $50 \%$ to fine-particle interactions. The latter is based on observations of oil in the form of a broken surface slick, resulting from physical abrasion, and of dispersed oil droplets resulting from the fineparticle interactions. The dispersed droplets were examined by light and electron microscopy, GC/MS, and by X-ray diffraction to verify the character of the flocs, the oil and the clays.

The primary alternative to the in situ treatment of oiled sediments is removal. At both of these spill incidents, scientific support was an important aspect of the decision process for selection of treatment options. The presentation of a reasoned case to the command team resulted in decisions that enabled operations to enhance the natural dispersion of the stranded oil by sediment relocation $[12,14]$. These two response operations illustrate an important step for shoreline treatment.

\section{SEDIMENT RELOCATION ('SURF WASHING') AND OFI}

From a process viewpoint, it is important to recognize that there is a distinction between the range of interactions known collectively as Oil and Fine-particle Interaction ('OFI') and the treatment technique of sediment relocation or 'surf washing', even though these two may occur concurrently.

1 At one end of the spectrum is a process that occurs as a result of mechanical abrasion alone.Wave or surf action provides physical (hydraulic) energy for the movement of sediments and the subsequent mechanical abrasion of oil from the surface of those sediments. Such an abrasion process can occur in the absence of fine particles. The treatment action in this case is to relocate or push oiled surface or subsurface sediments from above the intertidal zone (above the limit of wave action) or from the upper intertidal zone, to a lower part of the swash zone where energy levels are higher, thus accelerating this mechanical abrasion process.

2 The other action can take place in the absence of mechanical wave energy. This involves only interactions between oil and fine particles, in the presence of water. Oil is removed by tidal waterlevel changes or other in situ flushing actions. The cleanup action in this instance is to relocate or push sediments around to make the oil more available and so accelerate this physical interaction.

These two processes are completely different. Sediment relocation or 'surf washing' is an appropriate name for the first but not the second action. The latter occurs essentially without physical abrasion or mixing, and it has been recommended that this process should be referred to as Oil and Fine-particle Interaction or 'OFI'. The intent of the two treatment activities also is very different, the first is to accelerate abrasion and the second to accelerate OFI. However, most locations and spill response 
situations would fall somewhere in between these two conditions and the 'cleaning' likely would result from some combination of the two types of processes. In the Tampa Bay spill, wave action was minimal ('breakers' less than $10 \mathrm{~cm}$ ) and so the dominant process there would have been oil and fine-particle interaction with only very minor physical abrasion [12]. Similarly, the Sea Empress cleanup on Amroth beach occurred at a time of low wave action [13]. In the cases of the BIOS site, many of the Arrow sites, and the sheltered Exxon Valdez sites, wave energy was virtually absent and the oil-fine particle interaction would have occurred without natural 'surf' action [6 and 15).

In the case of both the Tampa Bay and the Sea Empress operations, accelerated cleaning was carried out by pushing oiled sediments from the upper intertidal and supratidal zones down the beach into the lower intertidal zone deliberately, during periods of little or no wave action, to accelerate the oil-fine particle interactions after physical removal of the bulk oil from the surface and subsurface beach sediments. The objective here was to intentionally accelerate fine-particle interaction, rather than to clean by anticipated physical abrasion.

Surf washing often may well include a component of fine-particle accelerated cleaning, even though abrasion and hydraulic removal are the primary cleaning actions. Surf washing has been carried out on many occasions (Table 2), however, the process that we now recognize as OFI was not the prime reason or the driving force behind the response in these examples except for the Tampa Bay and the Sea Empress operations.

Table 2 Recent examples of sediment relocation or surf washing as a cleanup tool

\begin{tabular}{|c|c|c|c|}
\hline Year & Incident & Remarks & References \\
\hline 1985 & Arco Anchorage & $\begin{array}{l}\text { Port Angeles, USA: 'Muck Monster' } \\
\text { used in shallow water to agitate } \\
\text { sediments and release oil }\end{array}$ & 16,17 \\
\hline 1990 & Exxon Valdez & $\begin{array}{l}\text { Berm relocation to accelerate oil } \\
\text { removal by abrasion }\end{array}$ & 18 \\
\hline 1991 & Kuwait spills & Arabian Gulf & 19 \\
\hline 1993 & Tampa Bay & $\begin{array}{l}\text { Florida USA: used intentionally for the } \\
\text { first time, observed but not documented }\end{array}$ & 12 \\
\hline 1994 & Fujayrah & $\begin{array}{l}\text { agitation to accelerate oil removal by } \\
\text { abrasion }\end{array}$ & $\begin{array}{l}\text { H. Parker, ITOPF, } \\
\text { personal communication }\end{array}$ \\
\hline 1994 & Apollo Sea & $\begin{array}{l}\text { South Africa: sediment relocation to } \\
\text { accelerate oil removal by abrasion }\end{array}$ & 20 \\
\hline 1996 & Sea Empress & $\begin{array}{l}\text { Wales: relocation used intentionally to } \\
\text { accelerate clay-oil flocculation; cleanup } \\
\text { and results well documented }\end{array}$ & 13,14 \\
\hline
\end{tabular}

\section{OFI AND BIOREMEDIATION}

Rates of biodegradation and bioremediation are controlled, in part, by the accessibility of oil surfaces to bacteria, nutrients, and oxygen. Bragg et al. recognized that the clay-oil flocculation process, which can produce small, micron-size particles at a rapid rate, is closely related to biodegradation [21]. If clay-oil flocculation and other aggregation processes occur naturally, or can be induced or accelerated, then the rates of biodegradation and/or bioremediation also can be accelerated when nutrients are not limited. This relationship has been demonstrated in the laboratory by Lee et al. [22]. Shaker flask experiments demonstrated that residual oil is effectively dispersed as a stable aggregate that prevents recoalescence. This interaction enhances oil degradation by increasing the surface area of the oil accessible to dissolved nutrients, oxygen and oil degrading bacteria. Specifically, the time series showed that OFI advanced the onset of biodegradation and that the addition of mineral fines caused a significant increase in total $n$-alkane loss rates over a 56-day period (Fig. 4).

This study is important in the context of the fate of particles generated by OFI. If the dispersed oil merely moves from one location (a shore) to another environmental compartment (the nearshore subtidal 


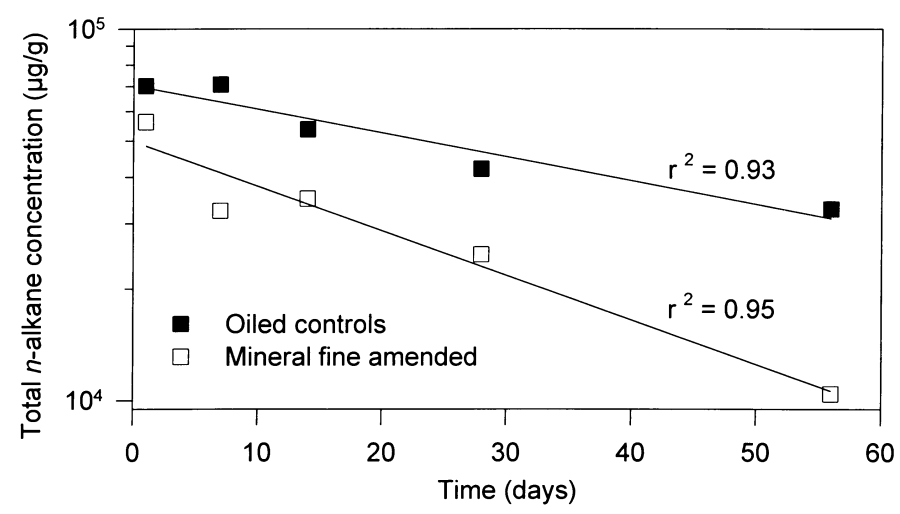

Fig. 4 Change in total $n$-alkane ( $n$-C12 to $n$-C35) concentration between Day 1 and Day 56 in oiled controls and mineral fine amended samples (from [22]).

sediments) then no significant ecological advantage has been gained by treatment actions. These laboratory results show that oil-mineral fine interactions stimulate microbial activity by enhancing both the rate and extent of oil degradation.

\section{APPLICATIONS}

The key findings to date are as follows:

1 Stranded oil can be broken down or weathered, in place, into its component parts in the absence of mechanical wave energy. This weathering can include a number of surface interaction processes, one of which is clay-oil flocculation $[8,15]$

2 Once small particles have been generated by this process they are more available for biodegradation [21]. Oil biodegradation rates can be enhanced by accelerating the interaction of oil with fine particles [22].

3 It is believed that these processes will eventually remove and break down all residual stranded oil, except in a few unusual circumstances. This explains why so little oil remains from the thousands of kilometers of shoreline that have been oiled over the years. Oil may remain unaffected by these fineparticle interaction processes if it is:

(a) above water level limits - stranded above the higher high-water mark and so not in contact with water, or

(b) semisolid or has a solid/semisolid (asphalt) 'skin' — so that the forces of cohesion are too strong and prevent small particles from breaking away from the oil surface.

4 The studies conducted to date have involved a range of oil types, both inorganic and organic particles, marine and freshwater environments, and oil that has been spilled and degraded in the arctic, midlatitudes, and the tropics. This wide range of conditions suggests that OFI potentially can occur for most oil types in most environmental settings. However, the rates at which the various OFI processes occur for different oil and particle types and in different environmental settings are unknown.

Another general point that emerged from the various field and laboratory studies is that stranded oil may appear fresh, even after many years, but only is fresh chemically (i.e. retains any of the lighter ends) if it is sealed in the sediments [9]. The fresh appearance results from the continuous stripping of the surface of the stranded oil by fine-particle interaction that prevents oxidation.

Many aspects of OFI have yet to be explored and investigated. The scale of the processes and the size of the particles are very small, less than $100 \mu \mathrm{m}$, and the formation of aggregates is very evident when viewed under the microscope. However, no standard accepted measurement technique has been developed for use in operations to enable immediate identification of the process, or the potential for the process to occur. Of greater importance is that the factors that control or affect the rates of natural oil 
removal by this process are not well understood. Laboratory tests [15] and field observations [9] show that, even after many ( $>22$ ) years, very viscous oils can be continuously weathered by this process, albeit at relatively slow rates. Tests also show that the processes can occur in freshwater samples (such as the Great Lakes), but not in distilled water. However, we do not know the role or significance of a wide range of surface interaction processes, nor the effect on rates and the extent of OFI in terms of varying characteristics of the oils, particles, or the carrying medium.

\section{CONCLUSIONS}

Field and laboratory studies have shown clearly that the group of physical processes referred to as Oil and Fine-particle Interactions ('OFI') can and does remove stranded oil residues from shorelines. There now exists an explanation for the natural self-cleaning of oiled shorelines in the presence and in the absence of both wave-energy and coastal erosion. OFI is one of a number of processes that actively promote the degradation and removal of stranded oil in low-energy environments. The significant point is the recognition of OFI as a contributing factor and that this group of physical processes now will have to be considered in all future investigations on the fate and persistence of stranded oil.

OFI has a wide application as a response option in relation to activities such as mixing and sediment relocation ('surf washing')[23]. Laboratory work has shown that OFI enhances oil degradation by increasing the surface area of the oil accessible to dissolved nutrients, oxygen and oil degrading bacteria. Importantly, time series investigations have shown that OFI can advance the onset of biodegradation and that the addition of mineral fines can cause a significant increase in oil loss rates.

Recognizing that OFI can occur or is taking place at an oiled site is presently a subjective visual technique. Laboratory tools, such as laser con-focal or UV-epifluorescence microscopy techniques can clearly distinguish between clays and oils [24]. However, these techniques are too complicated for the field. A field technique is required that can definitively identify and demonstrate that OFI occurs to provide a wider understanding of the process for the decision makers and to enable the generation of effective and confident technical support during the selection of appropriate treatment options.

The process of flocculation may be associated with an electrostatic attraction between the clays and polar compounds in the oil. However, the success of the relocation at the Tampa Bay spill as demonstrated in the laboratory, in the absence of mineral clays, pointed towards processes other than clay flocculation as contributing to the removal and dispersal of oil particles. Studies of surface kinetics and process dynamics associated with fine particles and on interactions between fines have defined wellestablished relationships that describe the mechanisms by which various particles bind and join together. The processes of aggregation, coagulation, and flocculation have been studied extensively, and it is likely that all of these play a role, under differing conditions, in the breakdown of oil. There is a complex interplay between viscous and interfacial forces which has yet to be investigated with respect to oils of differing viscosities and to oil-droplet formation. Similarly, although the formation of emulsions can be explained by colloidal chemistry, the solids-to-oil size ratios are not known and could be a critical stabilization parameter.

One consequence of understanding the range of processes that may be involved in cleaning due to fines has been the recommendation that the group of processes be termed Oil and Fine-particle Interaction ('OFI'), rather than referred to as a single process. In real-world situations, more than one process likely could be active concurrently even if one is dominant or prevailing.

Studies have shown that OFI has occurred in climates ranging from the arctic to the tropics and in both marine and fresh waters. OFI has been observed to promote the dispersion and degradation of 22-year old bunker $\mathrm{C}$, other heavy and medium fuels, and a number of different crude oils, including Alaska North Slope blend and emulsified Forties blend. However, the topic of oil-fine particle interaction has many unknowns at this time. Factors that control the different surface-interaction processes and the rates at which the different processes take place are not defined. Accelerated shoreline cleaning and enhanced oil biodegradation can be used in certain spill response situations, but until further investigations provide a more complete knowledge base, we will not be able to fully understand and exploit the potential for the use of Oil and Fine-particle Interaction as a response tool. 


\section{ACKNOWLEDGEMENTS}

This review has drawn heavily on the work of those investigators who have studied OFI over the past seven years and has benefitted directly from discussions with Dr Jim Bragg (Exxon Production Research Company), Blair Humphrey (Enviroed) and Dr Salim Abboud (Alberta Research Council). A review by Dr Ken Lee (Canadian Federal Government, Department of Fisheries and Oceans), himself a major contributor to the topic, is gratefully acknowledged.

\section{REFERENCES}

1 J. R. Bragg, S. H. Yang, J. C. Roffall. Experimental studies of natural cleansing of oil residue from rocks in Prince William Sound by wave/tidal action. Unpublished report, Exxon Production Research Co., Houston, TX 77252 (1990).

2 P. A. Meyers, J. G. Quinn. Association of hydrocarbons and mineral particles in saline solution. Nature 244, 23 24 (1973).

3 J. R. Payne, J. R. Clayton, G. D. McNabb, B. E. Kirstein, C. L. Clary, R. T. Redding, J. S. Evans, E. Reimnitz, E. W. Kempema. Oil-ice-sediment interactions during freeze up and breakup. US Department of Commerce, National Oceanographic and Administration (NOAA), OCSEAP final report, 64, 1-382 (1989).

4 H. O. Jahns, J. R. Bragg, L. C. Dash, E. H. Owens. Natural cleaning of shorelines following the Exxon Valdez spill. In Proc. Int Oil Spill Conference, pp. 167-176, Publication no. 4529. American Petroleum Institute, Washington, DC (1991).

5 J. R. Bragg, E. H. Owens. Clay-oil flocculation as a natural cleansing process following oil spills-Part 1: Studies of shoreline sediments and residues from past spills. In Proceedings 17th Arctic and Marine Oilspill Program (AMOP) Technical Seminar, pp. 1-23. Environment Canada, Vancouver, BC (1994).

6 E. H. Owens, J. R. Bragg, B. Humphrey. Clay-oil flocculation as a natural cleaning process following oil spills: Part 2-Implications of study results in understanding past spills and for future response decisions. In Proceedings 17th Arctic and Marine Oilspill Programme (AMOP) Technical Seminar, pp. 25-37. Environment Canada, Edmonton, Alberta (1994).

7 E. H. Owens. Changes in shoreline conditions 2 years after the 1989 Prince William Sound spill. Unpublished report by Woodward-Clyde Consultants, Seattle, WA, plus Appendices (1991).

8 J. R. Bragg, S. H. Yang. Clay-oil flocculation and its effects on the rate of natural cleansing in Prince William Sound following the Exxon Valdez oil spill. In Exxon Valdez Oil Spill-Fate and Effects in Alaskan Waters (P. G. Wells, J. N. Butler, J. S. Hughes, eds), pp. 178-214, ASTM STP 1219. American Society for Testing and Materials, Philadelphia, PA (1995).

9 E. H. Owens, B. Humphrey, G. A. Sergy. Natural cleaning of oil on two coarse-sediment shorelines on the Arctic and Atlantic coasts of Canada. Spill Sci. Technol. Bull. 1(1), 37-52 (1994).

10 E. H. Owens, M. A. Rashid. Coastal environments and oil spill residues in Chedabucto Bay, Nova Scotia. Can J. Earth Sci. 13(7), 908-928 (1976).

11 E. H. Owens, B. Humphrey, G. A. Sergy. The migration of stranded oil from a sheltered beach into adjacent nearshore subtidal sediments. In Fate and Effects of Oil in Marine Ecosystems (J. Kuiper, W. J. van den Brink, eds), pp. 231-241. Martinus Nijhoff Publishers BV, Dordrecht, the Netherlands (1987).

12 E. H. Owens, R. A. Davis Jr, J. Michel, K. Stritzke. Beach cleaning and the role of technical support in the 1993 Tampa Bay spill. In Proc. Int. Oil Spill Conference, pp. 627-634, Publication no. 4620. American Petroleum Institute, Washington, DC (1995).

13 K. Lee, T. Lunel, P. Wood, R. Swannell, P. Stoffyn-Egli. Shoreline cleanup by acceleration of clay-oil flocculation processes. In Proceedings 1997 Int. Oil Spill Conference, pp. 235-249, Publication no. 4651. American Petroleum Institute, Washington, DC (1997).

14 T. Lunel, K. Lee, R. Swannell, P. Wood, J. Rusin, N. Bailey, C. Halliwell, L. Davies, M. Sommerville, A. Dobie, D. Mitchell, M. McDonagh. Shoreline clean up during the Sea Empress incident: the role of the surf washing (clay-oil flocculation), dispersants, and bioremediation. In Proceedings 19th Arctic and Marine Oilspill Programme (AMOP) Technical Seminar, pp. 1521-1540. Environment Canada, Calgary, Alberta, (1996).

15 J. R. Bragg, E. H. Owens. Shoreline cleansing by interactions between oil and fine mineral particles. In Proc. Int. Oil Spill Conference, pp. 216-227, Publication no. 4620. American Petroleum Institute, Washington, DC (1995). 
16 R. A. Levine. Operational aspects of the response to the Arco Anchorage oil spill, Port Angeles, Washington. In Proceedings 1987 Oil Spill Conference, pp. 3-7, Publication no. 4452. American Petroleum Institute, Washington, DC (1987).

17 J. A. Miller. Beach agitation for crude oil removal from intertidal beach sediments. In Proceedings Int. Oil Spill Conference, pp. 85-90, Publication no. 4452. American Petroleum Institute, Washington, DC (1987).

18 E. H. Owens, A. R. Teal, P. R. Haase. 1991. Berm relocation during the. shoreline cleanup program following the 'Exxon Valdez' oil spill. In Proceedings 14th Arctic and Marine Oilspill Programme (AMOP) Technical Seminar, pp. 607-630. Environment Canada, Edmonton, Alberta (1990).

19 R. L. Benson, R. S. LeGore, D. Pascoe. A mechanized approach to beach cleanup in Saudi Arabia. In Proceedings 1993 Int. Oil Spill Conference, pp. 123-126, Publication no. 4580. American Petroleum Institute, Washington, DC (1993).

20 A. Molden. Response to the Apollo Sea oil spill, South Africa. In Proceedings 1997 Int. Oil Spill Conference, pp. 777-781, Publication no. 4651. American Petroleum Institute, Washington, DC (1997).

21 J. R. Bragg, R. C. Prince, E. J. Harner, R. M. Atlas. Effectiveness of bioremediation for the Exxon Valdez oil spill. Nature 386, 413-418 (1994).

22 K. Lee, S. St. Pierre, A. M. Weise. Enhanced oil biodegradation with mineral fine particles. In Proceedings 20th Arctic and Marine Oilspill Programme (AMOP) Technical Seminar, pp. 715-722. Environment Canada, Vancouver, BC (1997).

23 E. H. Owens. Sediment relocation and tilling - underused and misunderstood techniques for the treatment of oiled beaches. In Proceedings 21 st Arctic and Marine Oilspill Programme (AMOP) Technical Seminar, pp. 857871. Environment Canada, Edmonton, Alberta (1998).

24 K. Lee, P. Stoffyn-Egli, P. A. Wood, T. Lunel. Formation and structure of oil-mineral fines aggregates in coastal environments. In Proceedings 21 st Arctic and Marine Oilspill Programme (AMOP) Technical Seminar, pp. 911921. Environment Canada, Edmonton, Alberta (1998). 